\title{
PENERAPAN MODEL PEMBELAJARAN KOOPERATIF PADA PELAJARAN MATEMATIKA DAN BAHASA INDONESIA DALAM MENINGKATKAN HASIL BELAJAR SISWA KELAS 3 SDN 154503 HUTABALANG 3
}

\author{
Asnaria Situmeang \\ Surel: asnariasitumeang@gmail.com
}

\begin{abstract}
ABSTRAK
Tujuan penelitian ini adalah meningkatkan penguasaan siswa terhadap materi pelajaran dengan menerapkan model pembelajaran kooperatif. Desain penelitian ini adalah penelitian tindakan kelas. Hasil belajar siswa pada mata pelajaran Matematika siklus pertama ditemukan mean 62.75, pada siklus kedua meningkat menjadi 70.75 dan pada siklus ketiga, perolehan mean siswa semakin meningkat lagi menjadi 85.50. Hasil belajar siswa pada mata pelajaran bahasa indonesia siklus pertama ditemukan mean 64.70, pada siklus kedua meningkat menjadi 72.25 dan pada siklus ketiga, perolehan mean siswa semakin meningkat lagi menjadi 87.25. Penelitian ini menunjukkan bahwa pemilihan model belajar kooperatif dalam perbaikan pembelajaran Matematika dan Bahasa Indonesia terbukti tepat.
\end{abstract}

Kata Kunci: Pembelajaran Kooperatif, Hasil Belajar, Siswa

\section{PENDAHULUAN}

Dalam setiap pembelajaran, setiap guru berharap agar siswa yang diberi pembelajaran memperoleh hasil belajar yang sebaik-baiknya sesuai dengan tujuan pembelajaran yang telah direncanakan. Tidak semua siswa yang mengalami pembelajaran memperoleh hasil belajar yang maksimal, bahkan makin banyak siswa yang mengalami kesulitan belajar.

Guru kurang mampu menggunakan metode yang bervariasi, hanya mengajarkan kemampuan aspek berpikir logis, kritis, dan kreativitas. Widodo (2002) menyebutkan bahwa semua siswa pada dasarnya memiliki potensi untuk mencapai kompetensi yang maksimal dalam belajar. Kompetensi siswa menyerap informasi dalam konteks belajar memiliki perbedaan jika dikaitkan dengan intensitas keterlibatannya dalam belajar secara individual.

Salah satu indikator keberhasilan proses pembelajaran ditunjukkan oleh tercapainya tujuan pembelajaran oleh siswa. Kegiatan pembelajaran yang efektif tidak dapat muncul dengan sendirinya, tetapi guru harus menciptakan pembelajaran yang memungkinkan siswa mencapai tujuan yang ditetapkan secara optimal (Muhsetyo, 2004).

Berbagai kendala dapat terjadi di dalam proses belajar mengajar.

Kepala Sekolah SD Negeri 154503 Hutabalang 3 
Guru dituntut kemampuannya untuk memfasilitasi terciptanya iklim yang kondusif bagi berlangsungnya proses belajar mengajar yang bermakna bagi siswa. Samsuddin (2003) menyatakan bahwa guru adalah fasilitator, tetapi juga guru dituntut untuk memiliki segala informasi yang dibutuhkan dalam kegiatan pembelajaran.

Tugas dan peran guru memang cukup kompleks. Selain itu juga, guru harus menguasai bahan yang diajarkan, harus mampu mendidik dan memotivasi siswa agar tumbuh sebagai individu yang mandiri. Dalam pengelolaan proses belajar mengajar, guru harus menciptakan iklim belajar yang kondusif bagi berkembangnya kapasitas atau potensi siswanya (Suciati, 2004). Dengan pemahaman tersebut diharapkan guru mampu memilih dan menetapkan metode, strategi atau model pembelajaran yang tepat atau sesuai digunakan untuk mencapai tujuan pembelajaran, terutama pada mata pelajaran matematika dan bahasa indonesia.

Oleh karena itu, untuk meningkatkan penguasaan siswa terhadap materi pelajaran matematika dan bahasa indonesia, perlu dilakukan perbaikan pelaksanaan pembelajaran. Perbaikan pembelajaran ini dilakukan dengan menerapkan model pembelajaran kooperatif (cooperative learning). Model pembelajaran kooperatif diperkirakan dapat meningkatkan partisipasi siswa dalam kegiatan belajar. Pemilihan metode pembelajaran kooperatif didasarkan pada partisipasi siswa dalam kegiatan akan meningkat ketika dilakukan dalam suasana kerja sama dengan siswa lain (Widodo, 2002). Berkaitan dengan hal itu, secara teoritis, pembelajaran kooperatif merupakan pendekatan pembelajaran yang berfokus pada penggunaan kelompok kecil siswa untuk bekerja sama (Nurhadi, 2000)

Berdasarkan observasi peneliti pada siswa kelas tiga di SD Negeri 154503 Hutabalang 3, Kabupaten Tapanuli Tengah didapatkan bahwa tingkat kemampuan siswa menguasai materi yang diajarkan masih rendah dan belum mencapai standar kompetensi. Berdasarkan hasil ulangan yang dilakukan pada kedua mata pelajaran tersebut, siswa baru mampu mencapai daya serap terhadap materi pelajaran pada kisaran 50\% untuk pelajaran matematika dan $55 \%$ untuk pelajaran bahasa indonesia. Selain itu, dari 28 orang siswa kelas tiga, hanya lima orang siswa yang mampu memperoleh nilai 70 ke atas pada mata pelajaran matematika dan sebelas orang pada mata pelajaran bahasa indonesia.

\section{METODE PENELITIAN}

Penelitian ini adalah
penelitian tindakan kelas. Proses
penelitian dilakukan dimualai pada
tanggal 16 Maret-31 Maret 2015.
Populasi penelitian adalah siswa kelas


tiga sekolah dasar di SD Negeri 154503 Hutabalang 3 sebanyak 28 siswa. Pengambilan sampel dilakukan dengan teknik total sampling. Pengambilan data dilakukan dengan tiga siklus pada setiap mata pelajaran

\section{HASIL DAN PEMBAHASAN}

Berdasarkan pengolahan data perbaikan pembelajaran matematika, hasil belajar siswa pada mata pelajaran tersebut telah dapat ditingkatkan. Hasil belajar siswa pada mata pelajaran matematika siklus pertama ditemukan mean 62.75 , pada siklus kedua meningkat menjadi 70.75 dan pada siklus ketiga, perolehan mean siswa semakin meningkan lagi menjadi 85.50.

Tabel 1. Distribusi Mean Hasil Belajar Matematika pada Siklus Pertama Sampai Ketiga Tahun $2015(\mathrm{~N}=28)$

\begin{tabular}{ll}
\hline Siklus & Mean \\
\hline I & 62.75 \\
II & 70.75 \\
II & 85.50 \\
\hline
\end{tabular}

Pada perbaikan pembelajaran bahasa indonesia, juga menunjukkan peningkatan yang cukup baik mulai dari siklus pertama hingga siklus ketiga. Pada siklus pertama, mean yang diperoleh siswa adalah sebesar 64.70. Pada siklus kedua terjadi peningkatan mean menjadi 72.25 . Akhirnya dan pada siklus ketiga, perolehan mean siswa semakin meningkat lagi menjadi 87.25.

Tabel 2. Distribusi Mean Hasil Belajar Bahasa Indonesia pada Siklus Pertama sampai Ketiga Tahun $2015(\mathrm{~N}=28)$

\begin{tabular}{ll}
\hline Siklus & Mean \\
\hline I & 64.70 \\
II & 72.25 \\
II & 87.25 \\
\hline
\end{tabular}

Penerapan model belajar kooperatif dalam pembelajaran matematika dan bahasa indonesia telah berhasil menciptakan suasana kelas belajar yang dinamis, interaktif, kreatif, dan kompetitif. Siswa terdorong atau termotivasi membangun pengetahuannya sendiri berdasarkan pengalaman bekerja sama dalam tim kelompok belajar. Wahyudin (2002) mengatakan bahwa prestasi belajar siswa dalam pembelajaran akan meningkatkan ketika suasana kondusif bagi berkembangnya motivasi belajar siswa. Keberanian siswa mengajukan dan menjawab pertanyaan guru juga terlihat meningkat.

Pengembangan pembelajaran dengan model belajar kooperatif, tampaknya layak menjadi pilihan solusi untuk mengatasi masalah rendahnya daya serap siswa terhadap materi pembelajaran. Di samping itu, dengan menerapkan model belajar kooperatif diyakini akan mampu mengatasi masalah rendahnya 
partisipasi siswa dalam belajar. Santosa (2006) mengatakan bahwa kelas belajar yang dikelola dengan model belajar kooperatif merupakan solusi yang tepat mengatasi permasalahan rendahnya partisipasi siswa dalam belajar. Guru dituntut kemampuannya untuk menciptakan situasi kelas yang memungkinkan terjadi pembelajaran kooperatif.

Jika dikaitkan dengan temuan hasil penelitian ini, tampaknya perbaikan hasil belajar matematika dan bahasa indonesia telah berhasil dilakukan dengan menerapkan model belajar kooperatif (cooperative learning). Hal ini berarti, model belajar kooperatif telah dapat meningkatkan partisipasi siswa dalam kegiatan belajar sehingga dapat meningkatkan hasil belajar. Pemilihan model belajar kooperatif dalam perbaikan pembelajaran matematika dan bahasa indonesia terbukti tepat karena dapat meningkatkan partisipasi dan hasil belajar. Isjoni (2007) mengatakan bahwa model belajar kooperatif merupakan pendekatan pembelajaran yang berfokus pada pengembangan kelompok kecil siswa untuk bekerja sama dalam memaksimalkan kondisi belajar untuk mencapai tujuan pembelajaran.

\section{SIMPULAN}

Hasil penelitian menunjukkan bahwa penerapan model belajar kooperatif dalam pembelajaran matematika dan bahasa indonesia telah berhasil menciptakan suasana kelas belajar yang dinamis, interaktif, kreatif, dan kompetitif. Dengan menerapkan model belajar koooperatif, siswa termotivasi membangun pengetahuannya sendiri berdasarkan pengalaman bekerja sama dalam tim kelompok belajar. Hasil belajar siswa dalam mata pelajaran Matematika dan Bahasa Indonesia dengan menerapkan model belajar kooperatif semakin meningkat secara signifikan.

Temuan dalam penelitian ini menganjurkan guru untuk senantiasa memperbarui pengelolaan kegiatan belajar mengajar dengan menerapkan model belajar kooperatif yang disesuaikan dengan tuntutan kebutuhan belajar siswa. Selain itu juga, temuan dalam penelitian ini harus tetap mempertimbangkan perbedaan kapasitas dan potensi siswa secara individual, sehingga dimungkinkan untuk memanfaatkan perbedaan itu sebagai sarana pengembangan tutor sebaya diantara siswa.

\section{DAFTAR RUJUKAN}

Isjoni, H. (2007). Cooperative learning. Bandung: Alfabeta.

Muhsetyo, G. (2004). Pembelajaran matematika SD. Jakarta: Universitas Terbuka.

Nurhadi. (2002). Berbagai pendekatan pembelajaran. 
Malang: Universitas Negeri Malang.

Samsuddin, A. (2003). Profesi keguruan 2: Materi pokok program S1 PGSD. Jakarta: Universitas Terbuka.

Santosa, P. (2006). Materi dan pembelajaran bahasa indonesia : Materi pokok program S1 PGSD. Jakarta: Universitas terbuka.
Suciati. (2004). Belajar dan pembelajaran: Materi pokok program S1 PGSD. Jakarta: Universitas Terbuka.

Wahyudin, D. (2002). Pengantar pendidikan. Jakarta: Universitas terbuka.

Widodo, M. (2002). Strategi belajar mengajar efektif. Yogyakarta: Rineka Cipta. 